Canadian Science Publishing

Canadian Journal of Earth Sciences Revue canadienne des sciences de la Terre

\title{
Late-Glacial and Holocene evolution as a driver of diversity and complexity of the northeastern North American alpine landscapes: A synthesis
}

\begin{tabular}{|r|l|}
\hline Journal: & Canadian Journal of Earth Sciences \\
\hline Manuscript ID & cjes-2016-0004.R1 \\
\hline Manuscript Type: & Article \\
\hline Date Submitted by the Author: & 31 -Mar-2016 \\
\hline Complete List of Authors: & $\begin{array}{l}\text { Martin, Jean-Philippe; Universite du Quebec a Montreal, Institut des } \\
\text { Sciences de l'environnement } \\
\text { GERMAIN, Daniel; Universite du Quebec a Montreal, Département de } \\
\text { Géographie; Universite du Quebec a Montreal, Institut des Sciences de } \\
\text { IN'environnement }\end{array}$ \\
\hline Keyword: & Holocene, Alpine environment, Paraglacial, Resilience, Synergy \\
\hline
\end{tabular}


1 Late-Glacial and Holocene evolution as a driver of diversity and complexity of the

2 northeastern North American alpine landscapes: A synthesis

3

4 Jean-Philippe Martin ${ }^{1}$ and Daniel Germain ${ }^{1,2}$

5

$6 \quad{ }^{1}$ Institute of Environmental sciences, Université du Québec à Montréal, Canada.

$7 \quad$ martin.jean-philippe.3@courrier.uqam.ca

$8 \quad{ }^{2}$ Geography Department, Université du Québec à Montréal, Canada

$9 \quad$ germain.daniel@uqam.ca

10

\section{Corresponding author}

12 Jean-Philippe Martin, Institute of Environmental sciences, Université du Québec à Montréal,

13 P.O. Box 8888, Station Centre-Ville, Montreal, Quebec, Canada, H3C 3P8.

14 Phone: 1514 987-3000 \#6455

15 Email: martin.jean-philippe.3@,courrier.uqam.ca 


\section{Abstract}

27 Mid-altitude, mid-latitude mountains are complex environments due to their Pleistocene glacial

28 heritage, the importance of geomorphic processes on the steep slopes, and the climatic conditions

29 which are often close to periglacial. These factors, along with the fragmentation of the alpine

30 habitats, enhance the topographic and floristic diversity of these environments in northeastern

31 North America. Through case studies, this synthesis underlines the interactions between the

32 geosphere (glacial, paraglacial, and periglacial processes), the atmosphere (climatic fluctuations)

33 and the biosphere (vegetation establishment and evolution to the present-day) that explain the low

34 elevation of the northeastern North American alpine environment and that testify to its

35 complexity. Vegetation established earlier in the southern ranges, following the same general

36 trend as the Laurentian Ice Sheet recession. However, local factors such as ice retreat, response to

37 global scale climate changes and paraglacial processes acted in synergy to increase the resilience

38 and to influence the occurrence of alpine landscapes. The establishment of the latter environment

39 can therefore be considered to be azonal. Finally, our findings highlight the lack of a conceptual

40 framework, systemic studies and multi-proxy reconstructions of alpine environments located at

41 the limit of bioclimatic zones controlled by the equilibrium between biostatic and rhexistatic

42 regimes.

\section{Keywords}

45 Holocene, alpine environment, paraglacial, resilience, synergy 


\section{Introduction}

50

51 The diverse and combined influences of many orogenies - some in the recent past on a geological

52 timescale - with the many subsequent erosion agents, which depend on climatic variations at

53 local and regional scales, increase the complexity of the mountain environments and their

54 spatiotemporal evolution. If alpine glaciers and permafrost recession are at the heart of recent

55 scientific interest because of ongoing climatic change (e.g., Harris et al. 2009; Jomelli et al.

56 2011), the ecological evolution of alpine and subalpine environments at lower altitudes is equally

57 concerning (Grabherr et al., 2010; Engler et al., 2011; Dullinger et al., 2012). Indeed, mid-

58 altitude mountains are also foreseen to undergo profound modifications in the next decades and

59 century, hence the interest to better understand the past and ongoing evolution of these unique

60 environments which support a rich biodiversity, generate many natural georisks, and sustain

61 numerous anthropogenic activities and needs such as agriculture, water resources, tourism and

62 outdoor activities (Messerli and Ives 1997; Sagoff, 2002; Price et al. 2004).

64 While mid-altitude mountains often lack distinct glacial and periglacial levels, the presence of a

65 topographic gradient influences the development of a variety of environments with distinct

66 biophysical characteristics. In light of these observations, mid-altitude mountains should be

67 thought of as the outcome of a long and complex evolutionary process, the latter being driven by

68 non-linear feedbacks in space and time between many components of the geosphere (tectonics,

69 pre-Quaternary and glacial heritages, geological structure, sediment transfer processes), the

70 atmosphere (climatic variations at different spatial and temporal scales) and the biosphere

71 (vegetation cover, disturbance regime, ecosystem resilience). While recent recognition of

72 potential global-scale interactions between tectonics, climate, surface processes and vegetation 
73 dynamics is well documented (e.g., Winkworth et al. 2005; Bishop 2007; Whipple 2009), very

74 few examples are available in the scientific literature concerning mid-altitude mountains.

75 Moreover, the general lack of fine-scale temporal and spatial resolution in existing studies

76 impedes the provision of detailed information regarding the patterns and processes of these

77 systems' interactions.

79 In northeastern North America (i.e., latitude 43 to $50^{\circ} \mathrm{N}$ ), where the elevation of the treeline is 80 well below the worldwide pattern established by Körner (1998) (Figure 1), the low level of

81 human disturbance of the alpine and subalpine belts provides a unique opportunity to study and

82 document the synergistic influence of causal factors responsible for the current mountain

83 landscapes. At a regional scale, Cogbill and White (1991) reported the mean July temperature of

$8413{ }^{\circ} \mathrm{C}$ isotherm as a climatic control of the treeline in these mountain ranges. However, fine-scale

85 observations show significant discrepancies related to, among other factors, the proximity of the

86 ocean and climate variability, the toxicity of the serpentine bedrock, the importance of

87 geomorphic processes on steep slopes, and the ecological disturbance regime. It is the aim of this

88 paper to use case studies to illustrate the diversity of northeastern North American subalpine-

89 alpine environments as a complex evolution based on the timing of deglaciation, the pattern of

90 vegetation establishment, the frequency-magnitude of geomorphic processes and the ecological

91 disturbance regime, and their responses to climate variability throughout the Holocene epoch.

92 Future challenges and opportunities in the context of the ongoing global change will also be

93 discussed.

94

95 
97

98

99

100

101

102

103

104

105

106

107

108

109

110

111

112 Most of northeastern North America's current alpine environments were uplifted during the

113 Taconic or the Alleghenian phases of the Appalachian orogeny - $450 \mathrm{M}$ yrs ago and 325 to 260

114 M yrs ago respectively (Titus 2004). The difference in lithology between certain Appalachian

115 ranges has a profound ecological impact. For example, the Chic-Chocs Mountains are composed

116 of Ordovician limestone, shale, argilite, greywacke, as well as siltstone with occasional layers of

117 sandstone (Enos 1969). The Mont Albert plateau, one of the highest peaks of the range, can be

118 considered a distinct unit because of its high serpentine content which supports a unique flora

119 within the studied region (Sirois 1984). Intruded Devonian magmatic material forms the highest

120 summits of the range adjacent to the Chic-Chocs, the McGerrigle Mountains, which are 
121 composed mainly of granite and granitoid material (Gray and Brown 1979). The proximity of

122 these three distinct units (i.e., limestone, serpentine and granite) in an otherwise similar

123 environment in terms of topography and climate led early scientists to conclude that the geology

124 controlled the alpine floral diversity (Fernald 1907). The High Peaks of the Adirondack

125 Mountains and the Charlevoix Highlands are the only ranges from the Grenville Province,

126 composed mainly of Precambrian gneiss, granite and anorthosite (Hargraves and Roy 1974).

127 Table 1 presents the maximal elevation of the aforementioned ranges. The highest summit of the 128 study region is Mount Washington (1 $971 \mathrm{~m})$ in the White Mountains.

129

$130 \quad 2.3$ Alpine environment

131

132 The high mountains of northeastern North America follow a classical altitudinal zonation.

133 Montane mixed-coniferous forest covers the lower elevations, followed by a subalpine spruce-fir

134 or boreal forest, which spreads upward to the treeline. The alpine environment is defined as the

135 treeless, cold and windy high-altitude area above treeline on mountains (Löve 1970). In

136 northeastern North America, the alpine environment presents a mosaic of patches on the highest

137 summits, and not a continuous territory (Table 1). At the regional scale, there are gaps of many

138 hundreds of kilometers between the alpine ranges. At the range scale, alpine environments are

139 also distributed in patches, separated by forested valleys. The elevation of the treeline follows the

140 same decreasing trend along a latitudinal gradient that is observed worldwide (Figure 1). The

141 Chic-Chocs and the Long Range have the largest areas of land above the treeline. This is

142 consistent with the flat summit topography of these ranges, which are post-orogenic planation

143 surfaces (Jutras and Schroeder 1999), along with their higher latitude. 


\section{3. Methods}

146

147 The last decade has seen an increasing scientific interest in these altitude environments for

148 various reasons such as the increase of extreme hydrometeorological events (Germain and Hétu, 149 in press), the decrease of the woodland caribou populations in Quebec (Johnson et al., 2015) or

150 the response of the arctic-alpine flora to the ongoing climate changes (Bailey et al., 2015). The

151 onset of different initiatives demonstrate this renewed interest: a yearly occurrence of the

152 workshop entitled Northeast Alpine Stewardship Gathering, the publication of the Eastern Alpine

153 Guide (Jones and Willey, 2012) - a book about wildness and conservation with the contribution

154 of twenty authors, most of them scientists - and a scientific paper highlighting research priorities

155 and the need for a network of long-term alpine monitoring sites where a standardized protocol

156 would be used to collect data on biotic and abiotic parameters (Capers et al., 2013). In that

157 regards, two sites located in the Chic-Chocs Mountains (Quebec) and the White Mountains (New

158 Hampshire) were implemented following the international protocol of GLORIA (GLobal

159 Observation Research Initiative in Alpine environments) in the last few years. However, as

160 recently reported by Capers et al. (2013, p.559), research in alpine areas of northeastern North

161 America has been poorly coordinated, with minimal communication among researchers, and it

162 has rarely been multidisciplinary.

164 As a first attempt to address the aforementioned gap, the following results lean on a meta-

165 analysis of the existing literature about the glacial, palaeoecological and geomorphological

166 evolution of the mountain ranges of Northeastern North America. Indeed, there is a wide corpus

167 of papers in regional and international scientific journals that provide chronologies with regard to

168 the glacial retreat, the vegetation settlement, the evolution of geomorphic processes and systems. 
169 A bibliographic database containing 109 references was created (Supplementary material 1), but

170 to increase the readability, only the most relevant are integrated to this paper. We are aware that

171 the present analysis does not include every aspects of the alpine environment that is covered by

172 the scientific literature, such as the insects, the lichens, the mammals (especially the woodland

173 caribou), local climatology or the geology (lithology and past orogenies). Rather than an

174 exhaustive catalogue of every previous study done in the alpine environment of northeastern

175 North America, this work represents the first step of a transdisciplinary, large-scale analysis of

176 alpine environments since the Late-Glacial. It is the hope of the authors that this synthesis serves

177 as a starting point for more detailed analysis and scientific work about the long-term biophysical

178 conditions that characterise these mid-altitude mountains.

180 Tables 2 and 3 detail the sites and types of records that were used in the following glacial and

181 paleoecological reconstructions. Most of the chronological data are therefore derived from ${ }^{14} \mathrm{C}$

182 dates of pollen assemblages and macrofossils. Unless specified otherwise, all dates are given in

183 calendar years. CALIB 6.0 software (Reimer et al. 2009) was used to calibrate radiocarbon dates

184 with a standard deviation of 100 years when calendar dates were unavailable. Calibrated dates

185 were rounded to the nearest 100 years and are labeled Before Present (BP).

\section{4. Results and discussion}

189 The meta-analysis of the literature allowed the reconstruction of the chronology of the general

190 deglaciation and vegetation establishment throughout the study region. These general patterns

191 provide an overlook of the inception of alpine environments on the higher summits of

192 Northeastern North America. Different case studies are then presented in order to propose 
193 concepts that encompass the complex relationships explaining the local discrepancies in the

194 altitudinal and latitudinal localisation of the treeline. First, from a geomorphological standpoint,

195 the elasticity of the paraglacial period, explicated by local topographical, geographical and

196 geological factors, will influence nowaday's equilibrium between rhexistatic and biostatic

197 processes on the steep slopes. Next, the late-Holocene fluctuations in climate acted in synergy

198 with punctual ecological disturbances to create localized alpine environments on previously

199 forested summits. Finally, the inception and preservation of permafrost in the study regions,

200 along with the fact that the alpine treeline is controlled by disturbances rather than temperature,

201 explain the delicate balance between the sensitivity and the resilience of the alpine landscape.

202

4.1 Deglaciation pattern, vegetation establishment and regional climatic changes

\subsubsection{Deglaciation}

207 Although the patterns of deglaciation of the Appalachian Highlands and the supposed presence of 208 nunataks have been debated for nearly a century across the study area (Fernald 1925; Bradley

209 1981; Gosse et al. 2006; Olejczyk and Gray 2007), it is now well-established that the Laurentian

210 Ice Sheet (LIS) flowed across the mountain ranges and highlands of New England and Quebec,

211 and connected with regional ice caps in the Atlantic Provinces and in the Chic-Chocs Mountains

212 during the Last Glacial Maximum (LGM). The recession of the LIS in New England followed a

213 general South to North trend. The onset of the glacial recession is poorly dated; the best estimate

214 of its beginning is the onset of varved sedimentation at the south end of Glacial Lake Hitchcock

215 in southern Connecticut, at $15,600{ }^{14} \mathrm{C}$ yr BP (Dyke et al., 2002). The southwestern ice masses, 
216 such as the White Mountains ice cap, remained connected with the LIS, while the Gaspé

217 Peninsula and Newfoundland ice caps were isolated.

218

219 The approximate date of ice recession in the different alpine ranges covered in this paper is

220 presented in Figure 3. These data show the general trends, but any comparison between them

221 remains uncertain, since the recessional dates were determined by various proxies (Table 2) that

222 represent a range of spatial scale dynamics from regional (e.g. pollen) to local (e.g. gyttja).

223 Moreover, there is much variation in the elevation at which the data were derived. At the global

224 scale, New England was deglaciated before the Younger Dryas (12,900-11,400 BP). There is then

225 a long time gap before deglaciation begins in the northernmost ranges, which suggests that the

226 Younger Dryas delayed the melting of alpine ice caps located further north. In most ranges, the

227 timing of ice recession is consistent with the deglaciation isochrones map of Southern Quebec

228 and adjacent territories (Richard, 2009), with the exception of the White Mountains, for which

229 the local data are older. This implies that the regional scale pattern might not reflect the local

230 specificities of ice recession in the alpine ranges.

231

232 In the Gaspé Peninsula, variations in basal dates from different records are important to consider.

233 Some are much younger than others, which led Richard et al. (1997) to propose the presence of

234 late small glaciers in some of the cirques of the Chic-Chocs. While some hypotheses have been

235 proposed to explain the discrepancy (e.g., presence of an alpine desert or late ice), the absence of

236 direct evidence dictates that caution must be taken when interpreting regional trends from a

237 single or few basal dates.

238

239

4.1.2 Vegetation establishment

https://mc06.manuscriptcentral.com/cjes-pubs 
241 The postglacial vegetation establishment in northeastern North America followed three stages:

242 tundra, afforestation and closed-forest stages. The general chronology for the vegetation

243 dynamics of different mountain ranges is presented in Figure 3, which must, however, be treated 244 with caution for several reasons:

1) Contamination from organic carbon and radiocarbon accuracy. The dates from the Chic-

247 Chocs Highlands are from Richard et al. (1997), who demonstrated that the basal date of a

248 core sampled in 1979 was too old, due to the contamination of the dissolved $\mathrm{CO}_{2}$ by inactive

249 carbon from the bedrock. Based on this evidence, other dates are potentially too old at other

$250 \quad$ sites as well;

251 2) Altitude. The altitude at which the studies were conducted varies greatly, from the mixed-

252 coniferous montane forest to the upper limit of the spruce-fir subalpine belt;

253 3) Availability of accelerator mass spectrometry (AMS) dating. As for old carbon contamination,

254 AMS dating of macrofossils instead of total organic matter has allowed more accurate

255 chronologies. However, northeastern North American alpine paleoecology was mainly

256 published before 1995, when these dating techniques still were not widespread. However,

257 above the treeline in the alpine environment, the pollen influx is low. The pollen from distant

258 sites is over-represented and therefore allows only the reconstruction of the vegetation at the

259 regional level and makes the interpretation of treeline evolution particularly difficult; hence

260 the need for macrofossil analysis in treeless environments (Birks and Birks 2000).

262 At the regional scale, the vegetation establishment pattern in alpine environments followed the 263 ice recession during the Late-Wisconsinan (Figure 3), the southernmost ranges being colonized 
264 first. At Mount Katahdin, the tundra stage was synchronous with the Adirondacks and the White

265 Mountains, but the afforestation stage was longer and potentially delayed by the onset of the

266 Younger Dryas. Moreover, there is a wide temporal gap in the vegetation establishment between

267 the alpine ranges of New England and of Quebec (Figure 3). The proximity of the Quebec ranges

268 with the Gulf of St. Lawrence and the Atlantic Ocean would have increased the cooling effect of

269 the Younger Dryas compared with the southern, more continental ranges (Cwynar and Spear

270 2001), therefore making it impossible for vegetation establishment to begin during this climatic

271 period. Afterward, the recurrence of cold episodes following the Younger Dryas (Atlantic

272 Preboreal Oscillation and the 8,200 BP cooling period), enhanced by the proximity with the LIS

273 and a high volume of freshwater runoff in the St. Lawrence River, would have delayed it further

274 (Anderson et al. 2007).

275

276 There are however some discrepancies between the deglacial and paleoecological records. For

277 example, in the Charlevoix region, deglaciation is thought to have occurred around 12,500 BP at

278 low altitudes from the presence of the St. Narcisse moraine. However, the oldest record from

279 organic material in the Highlands dates from 10,500 BP. Two hypotheses could explain the gap

280 of 2,200 years between ice recession and vegetation establishment; i) like in the Gaspé Peninsula,

281 the Younger Dryas period might have been favourable to the build-up of alpine glaciers on the

282 highest summits of Charlevoix; ii) it is likely that an alpine desert occurred between the ice

283 recession and the tundra stage, such as reported for the Chic-Chocs Mountains.

284

285 This regional picture allows depicting the general trend of ice retreat and alpine environment 286 establishment along a SW - NE gradient. At the local scale, the following case studies illustrate 287 that complex interactions between geomorphological, ecological and climatic systems create a set 
288 of conditions for the establishment, the diversity and the preservation of the alpine environments 289 throughout the Holocene.

290

\subsubsection{Paraglacial time magnitude and elasticity impact on the alpine landscape}

295 The alpine landscapes of northeastern North America have been geomorphologically active since 296 the Late-Glacial period, but the frequency, magnitude and efficiency of the processes involved 297 have varied following deglaciation and the Holocene climatic fluctuations. The recession of the 298 LIS or the Appalachian ice caps exposed the landscape to paraglacial processes corresponding to 299 isostatic instability and high sediment availability, providing a context of high geomorphic 300 activity on the steep slopes. However, the scientific literature on Holocene hillslope 301 geomorphology in the alpine ranges of northeasterm North America comes almost exclusively 302 from the Gaspé Peninsula (regional synthesis are provided by Hétu and Gray 2000; Germain et 303 al. 2010), with few studies focusing on the present-day processes in the Adirondack Mountains 304 (e.g. Bogucki, 1977), the White Mountains (e.g. Kull and Magilligan, 1994), the Cape Breton 305 Highlands (e.g. Wahl et al. 2007) and the Newfoundland Long Range (e.g. Hiscott and James, 306 1985).

308 The paraglacial processes were central in shaping the alpine landscape in this region through their 309 dynamic interactions with ecological processes. Hillslope processes in the White Mountains 310 during the Early-Holocene rendered the vegetation establishment more complex. The beginning 311 of pollen accumulation was approximately synchronous at low (200 and $650 \mathrm{~m})$ and high (1,325 
312 and 1,542 m) altitudes (Spear et al. 1994). Before 13,500 BP, all these sites recorded tundra

313 vegetation. During this period, there is an absence of vegetation in the pollen records at mid-

314 elevation sites (1,140 and 1,275 m), the earliest ones corresponding to 11,500 BP. Spear et al.

315 (1994) suggested that the mid-altitude active steep slopes prohibited vegetation establishment

316 until their stabilization, which points to the role of paraglacial geomorphic agents in the

317 ecological evolution of the White Mountains.

318

319 The duration of the paraglacial period is directly related to the glacially conditioned sediment

320 availability and varies from 10 to $>10,000$ years. It is assumed that for an isolated landsystem,

321 the paraglacial period ends at the exhaustion of this sediment stock, the latter being characterized

322 by an exponential decline. However, secondary processes such as debris flows occurring in

323 primary paraglacial stock in scree slopes, can rework glacigenic sediments stored in primary

324 paraglacial stocks, further extending the duration of this period (Ballantyne 2002). Hétu and Gray

325 (2000) define the end of the paraglacial period in the northern Gaspé Peninsula as the complete

326 burial of the rock walls by rockfalls, and later reworking of the debris by dry grain flows, frost-

327 coated clasts flow, debris flows, snow avalanches and niveo-aeolian transport. At present, the

328 coastal valleys of the northern Gaspé Peninsula have a diachronous pattern of paraglacial

329 influences. For example, in the Mont Saint-Pierre valley, forest vegetation covers the east-facing

330 slopes where rockwalls have been almost completely eliminated, while on the west-facing slopes,

331 where summit rockwall segments are still active, the upper part of the scree slope is still devoid

332 of vegetation. As many studies highlight ( $c f$. Hétu and Gray 2000), the upper limit of the forest

333 on these slopes has been changing constantly throughout the Holocene, in response to

334 hydroclimatic conditions. A warmer and drier climate generally tends to favour an upward

335 movement of the treeline via a decrease in the frequency and magnitude of mass wasting 
336 processes; this tendency reverses in colder and wetter periods. However, the treeline on the scree

337 slopes of Mont Saint-Pierre has been extending upward from the end of the Little Ice Age until

338 1950. Since then, geomorphic processes have increasingly fragmented the treeline despite a

339 positive trend in the temperature (Lafortune et al., 1997). Therefore, vegetation dynamics and

340 paraglacial processes reach a dynamic equilibrium conditioned by complex geomorphic

341 responses to the changes in hydroclimatic conditions.

343 The differences in the duration of the paraglacial period are even more striking on a larger scale.

344 The Long Range and the Chic-Chocs contain similar drift-mantled landsystem based on similar 345 processes and with similar lithologies, and have been deglaciated for approximately the same

346 length of time. However, there seems to be an important difference in the efficiency and the

347 magnitude of the present-day geomorphic processes. For example, on the Tablelands in

348 Newfoundland, debris fans of a few hundred meters wide are common and still active, since they

349 are not colonized by vegetation at an altitude close to sea level. On Mont Albert in the Chic-

350 Chocs, debris fans of this magnitude are relict nowadays, but are superimposed by active debris

351 cones with a surface and debris size smaller by close to an order of magnitude (Germain 2005).

352 This hydrosedimentological transition appears related to hydroclimatic conditions, which were

353 favourable to the definitive closure of the regional forest cover as established by pollen analysis

354 (Hétu and Bail, 1996). This example underlines the importance of local ecological and

355 hydroclimatic conditions in controlling the duration of exhaustion of glacially conditioned

356 sedimentary stocks and consequently the delay of paraglacial responses of geomorphologic

357 landsystems. Moreover, the overlapping of landforms, such as the debris cones of different scales

358 on Mont Albert, is evidence of a more mature, postglacial landscape, with similar processes

359 driving the sediment cascade, but to a different magnitude. 
361 This section highlights the importance of the paraglacial concept to understanding the formation

362 of the northeastern North American montane landscape, as well as the ecological evolution of the

363 steep slopes by the rhexistatic forcing that influenced the vegetation establishment and vice versa.

364 Considering that the essence of the paraglacial concept is to define recently deglaciated areas that

365 are in an unstable geomorphological state, vulnerable to erosion processes, some slopes of the

366 mountain regions of northeastern North America are still influenced by paraglacial processes

367 more than 10,000 years after the onset of the Holocene period. This dichotomy between active

368 and relict paraglacial periods is visible at the local and regional scales. Therefore, not only is

369 there an overlapping of temporal scales amongst paraglacial periods from different landsystems

370 (Mercier 2008), but also an overlapping of spatial scales controlled by external variables such as

371 vegetation and hydroclimatic conditions.

372

373

4.2.2 Synergistic effects of climate change and ecological disturbances

374

375 The data in Figure 1 shows the expected negative relationship between the altitude of the treeline 376 and the latitude of the mountain range for northeastern North America. However, the altitude of

377 the treeline in some ranges, such as the White Mountains and the Charlevoix Highlands, is lower

378 than would be expected from this figure, as well as from a comparison with other mountain

379 ranges at similar latitudes around the world. While regional climatic latitudinal gradient as well

380 as deglaciation and vegetation establishment processes explain the general trend, local dynamics

381 are responsible for such discrepancies. As the following case studies demonstrate, it is not one

382 system that is directly responsible for the lower elevation of the treeline in certain ranges but

383 rather the synergistic effects of different systems. 
385 The subalpine spruce-fir forest composition of the Appalachians differs from that of the boreal 386 forest in disturbances controlling their dynamics, among other factors (Cogbill and White 1991).

387 The subalpine spruce-fir forest is controlled by wind and individual tree mortality (Sprugel 388 1976), whereas the boreal forest dynamics are mainly controlled by ecological disturbances such 389 as fire and insect outbreaks (Cogbill 1985).

391 The Charlevoix Highlands are located within the boreal forest belt. Charcoal found on a summit 392 was dated to 3,150 BP, which shows that it was previously forested and then decimated by fire 393 (Bussières et al., 1996). Today, open bogs occupy depressions in the upper slopes of these 394 summits. The low regeneration rate following these fires is probably due to the deterioration of 395 climatic conditions, since evidences of synchronous climatic cooling responsible for the increase 396 in fire activity have been recorded in Charlevoix and in the Gaspé Peninsula. The paludification 397 of the alpine zone is also indicative of a generally positive moisture surface balance during the 398 Neoglacial. This case highlights the azonal nature of alpine and subalpine altitudinal belts of the 399 Charlevoix Highlands, since they do not result from a climatic gradient associated with 400 topography, but rather from a modification in the ecological dynamics caused by the large-scale 401 Late-Holocene climatic deterioration.

403 In the White Mountains, the treeline of the subalpine spruce-fir forest moved upslope during the 404 Younger Dryas (between 12,900 and 11,500 BP), reaching altitudes higher than in the present405 day. This caused scientists to state that the Younger Dryas had not influenced the high-elevation 406 vegetation of the White Mountains (Spear et al. 1994). However, later studies based on loss-on407 ignition and chironomids suggest that even if there was an attenuation of the effects of this 
408 cooling episode westward from the Maritime provinces, the temperature of mid-altitude lakes in

409 the White Mountains dropped by approximately $5{ }^{\circ} \mathrm{C}$ during the Younger Dryas (Cwynar and

410 Spear 2001). Therefore, the treeline was highest in the White Mountains during one of the coldest

411 periods since ice recession. The beginning of Younger Dryas saw the occurrence of a shift from

412 northwesterly winds during the Bolling-Allerod period to northeasterly katabatic prevailing

413 winds in New England (Thorson and Schile 1995) and Quebec (Filion 1987). Present-day winds

414 at the top of Mount Washington are extremely strong (Gordon 1989), which is the result, among

415 other causes, of the orientation of the mountain range perpendicular to the prevailing winds. The

416 upward progression of the treeline at Mount Washington, controlled primarily by these extreme

417 winds and rime episodes, could be caused by this shift in prevailing winds to an axis more

418 parallel to the range, and thus decreasing their velocity. This anomaly in treeline position was

419 preserved during the warmer, Mid-Holocene climatic optimum to finally regress to its present

420 elevation during the Neoglacial, showing that the lower altitudinal limit of the alpine

421 environment in this area does not respond to cold episodes or strong winds individually, but

422 rather to a synergistic relationship between these two variables.

423

424

\subsubsection{Sensitivity and Resilience of the Alpine Landscape}

426 Permafrost. Permafrost patches are still present in the Charlevoix Highlands, Mont Jacques-

427 Cartier in the McGerrigles, Mount Washington in the White Mountains and in western

428 Newfoundland (Figure 4; Clark and Schmidlin, 1992). Except for the latter, these ranges are well

429 beyond the latitudinal limit of discontinuous permafrost distribution in Canada. Based on

430 temperature extrapolation, Walegur and Nelson (2003) estimated that the presence of permafrost

431 would be possible on the highest summits of the High Peaks of the Adirondacks (Mount Marcy 
432 and Whiteface) and of northern Maine (Sugarloaf Mountain, Snow Mountain, Crocker Mountain 433 and Mount Katahdin).

435 Permafrost is considered to be a system that is sensitive to ongoing and anticipated climate 436 change (Camill and Clark 2000). In the Chic-Chocs, however, 30 years of monitoring a 437 permafrost patch led to the conclusion that the latter is stable (Gray et al., 2009). The permafrost 438 of Mont du Lac des Cygnes in the Charlevoix Highlands is well below the elevation trend of the 439 other summits where permafrost bodies were observed. The approximate mean annual 440 temperature of around $0^{\circ} \mathrm{C}$ for adjacent summits would not be sufficiently cold for the inception 441 of permafrost. This suggests that it was formed during a colder period. In Charlevoix, the climatic 442 conditions during the Neoglacial were not cold enough to trigger the formation of perennially 443 frozen ground (Zimmerman and Lavoie 2001). Therefore, the permafrost islands in Charlevoix 444 are estimated to have formed during the Little Ice Age, in the last 500 years, in response to a 445 unique set of climatic and ecological conditions. Fires were very frequent in the Charlevoix 446 Highlands in the last 3,000 years (Bussières et al. 1996). The opening of the vegetation,

447 combined with the strong winds characteristics of this region and the cooling of the climate, led 448 to little snow accumulation on the summits and to deeper ground penetration of the frost wave 449 during the winter. The cool climate reduced evaporation and was favourable to the accumulation 450 of moss, which isolated the ground ice. These cases show that permafrost patches in this study 451 area are not climate driven, but their inception rather occurred in a precise eco-climatic context. 452 Since present-day ecological conditions are responsible for their resilience, they evolved into an 453 ecosystem-protected permafrost, which means that they are unlikely to recover after a significant 454 disturbance with the ongoing change in climate (Shur and Jorgenson, 2007). 
456 The resilience of mountain top permafrost in marginal environmental conditions at latitudes

457 lower than the regional pattern of permafrost distribution is surprising and must be caused by the

458 interaction of the different systems. While the mean annual air temperature following the Little

459 Ice Age got warmer, the absence of trees on the summit allowed the strong winds to cause

460 enough snow drifting to clear the snow or compact it sufficiently to increase its thermal

461 conductivity. Both cases would result in a negative mean annual ground temperature.

462

463 Rock glaciers. Rock glaciers are widespread in the study region. Many were identified at low (20

$464 \mathrm{~m})$ and high $(>600 \mathrm{~m})$ elevations in the Chic-Chocs and almost all of these rock glaciers were

465 located on a scree slope at the base of a rock wall. These objects form by the combination of

466 paraglacial processes and periglacial conditions (Humlum, 1998) that influenced the landscape

467 during the Late-Holocene. The distribution of the altitudinal limit of rock glaciers followed the

468 same latitudinal trend as present-day summit permafrost (Figure 4). Nowadays, most of these

469 features are relict, but there are some exceptions at surprisingly low altitudes in the Gaspé

470 Peninsula or in the Laurentian Highlands. Putnam and Putnam (2009) identified two inactive rock

471 glaciers with an ice core in Maine, at an altitude of less than $500 \mathrm{~m}$. However, these authors only

472 recorded the underground temperature for one year; therefore one cannot conclude that the ice

473 core lasted for a sufficient duration to be considered to be permafrost.

475 While there is no evidence of the sustainability of these ice cores beyond one year under present476 day conditions, their resilience to summer melting is still surprising at such low altitudes. Cold 477 talus scree slopes exhibiting a cold ventilation mechanism have been found at elevations close to 478 or even lower than the Early-Holocene permafrost altitudinal limits (Figure 4). Therefore, even if 479 it is impossible to conclude the interannual sustainability of these ice cores, the existence of 
480 sufficient winter frost ground penetration for the onset of a ventilation mechanism in some rock

481 glaciers and scree slopes at low elevations can be concluded, contributing to the thermal inertia of

482 the cores and delaying the melting, at least, to the end of the thawing season. Because of the

483 sporadic distribution of these ventilation systems in northeastern North America, we can

484 conclude that they are located at the boundary of the climatic conditions necessary for their

485 development. Hence, their onset must be controlled by the local topographic, geomorphologic,

486 and climatic conditions.

488 Given the latitude of the study region, it is unlikely that discontinuous permafrost is frequent at 489 such moderate elevations. However, these cold scree slopes create favourable conditions for the 490 annual conservation of ice, as reported elsewhere in mountainous environments under the

491 discontinuous permafrost limit (e.g., Morard et al. 2010; Gądek 2012). This dynamic testifies to

492 the increased complexity associated with local processes such as the ground thermal regime

493 among the paraglacial coarse-grained sediment stocks. More long-term data could permit insight

494 into whether there is an actual (discontinuous) permafrost regime at mid- to low altitudes in the

495 mountains of northeastern North America.

497 Treeline position. Altitudinal and latitudinal treelines and ecotones are often considered to be 498 sensitive to temperature, and hence to ongoing climate warming (Harsch et al. 2009). However, 499 the increase in the elevation of the treeline in response to climate change is heterogeneous at the 500 global scale. Harsch et al. (2009) reported an increase in elevation for $52 \%$ of the treelines at the 501 global scale and failed to associate the probability of treeline advance with either mean annual or 502 summer temperature increase, the latter being considered to be the main control over treeline 503 position (e.g., Cogbill and White 1991). At the Holocene temporal scale, since the establishment 
504 of alpine tundra at high elevations (ca. 9,000 BP), climatic fluctuations had significant impacts on

505 lower elevation vegetation assemblages, but they had little influence on alpine plant communities

506 (Spear 1989). At a smaller temporal scale, diachronic comparisons of treeline position all yield

507 the same results: the treeline is generally stable but the shrub species cover in the lower alpine

508 tundra increases (Robinson et al. 2010; Capers and Stone 2011; Dumais et al. 2014). However,

509 the few studies undertaken on the climate of mountain ranges in our study region did not find

510 significant trend in temperature or precipitation for high elevation sites (Seidel et al., 2009; Fortin

511 and Hétu 2014). At the regional scale, over the last four decades there has been a notable

512 warming trend in the mean annual temperature in Gaspé $\left(0.11^{\circ} \mathrm{C}\right.$ per decade; Yagouti et al.

$5132006)$ and in the mean winter temperature in the northeastern United States $\left(0.1^{\circ} \mathrm{C}\right.$ per decade;

514 Burakowski et al. 2008). However, one has to exercise extreme caution in the extrapolation of

515 general temperature trends to local alpine environments, especially with the quasi-absence of

516 high altitude weather stations with reliable long-term data in the current study region.

517

518 Other environmental conditions must control the treeline elevation resilience to climate warming.

519 Carlson et al. (2011) report that the alpine environment of the Adirondacks exhibits a spatial

520 pattern that corresponds with the prevailing wind direction, providing further evidence that the

521 alpine treeline of northeastern North America is primarily controlled by winds and winter icing

522 events. The treeline of our study region does exhibit the presence of a wind dominated

523 disturbance regime, since almost every tree community located in the subalpine-alpine ecotone

524 grows in krummholz. At the global scale it can be observed that, contrary to the diffuse treelines,

525 the krummholz treelines fail to exhibit a significant relationship between their upward

526 progression (or lack thereof) and temperature warming (Harsch et al. 2009). The krummholz

527 growth form of trees at the treeline forbidding the production of viable seeds, the lack of suitable 
528 germination sites on the mountaintop bedrock and felsenmeers, or the absence of a soil layer have

529 also been mentioned as factors restricting the upward progression of the treeline (Dumais et al.

530 2014). The presence of permafrost bodies on the concerned summits may also prevent the

531 progression of the treeline to higher elevations. The permafrost system and the treeline system

532 therefore mutually increase the resilience of one another. The permafrost limits the upward

533 progression of the treeline. The absence of trees above the treeline allows for higher wind speeds

534 and greater snow drifting from the summit, which, as was stated earlier, is a key factor in

535 allowing sufficient frost ground penetration for the conservation of the permafrost. The

536 permafrost lying on the summit of these mid-altitude mountains is thus particularly vulnerable

537 and depends on complex interactions between snow cover, vegetation and local climate

538 (Johansson et al. 2013).

539

540 Hence, as long as there are rime or ice storms episodes during the winter, the wood abrasion by

541 wind transported ice crystals and the mechanical breakage will prevent the upward progression of

542 the treeline (Rochefort et al. 1994). However, the Northern Hardwood Boreal Ecotone is

543 controlled by temperature, as reported by Beckage et al. (2008) who estimate an upslope shift of

5442.1 to $2.8 \mathrm{~m} \mathrm{yr}^{-1}$ in the Green Mountains. It is therefore the subalpine spruce-fir belt that is the

545 most vulnerable. The ongoing warming is expected to contribute to the narrowing of the altitude

546 range of the subalpine spruce-fir belt with an upward displacement of the underlying ecotone

547 (Carlson et al. 2011).

548

549

550 
5514.3 Holocene climate reconstruction in northeastern North American alpine landscapes-

552 discrepancies and the need for a multi-proxy approach

553

554 Figure 5 compares different indicators of Late-Glacial and Holocene climatic changes in the

555 alpine ranges of northeastern North America. From this synthesis, several statements can be 556 made:

557

558 1) Among different ranges across the studied region, there seem to be important differences in

559 the response to global scale Holocene climate fluctuations. There seem to be regional

560 differences between some of the climatic periods across the studied regions. For example,

561 from the vegetation records, there is a lag of approximately 2,000 years for the occurrence of a

562 Mid-Holocene climatic warming between New England and the Gaspé Peninsula.;

563 2) At local scale, there has been no clear evidence of the Younger Dryas episode from the pollen

564 records of the White Mountains (Spear et al. 1994). Indeed, these records suggest an opposite

565 trend, with the upward progress of the treeline due to shifting prevailing winds mentioned

566 above. Other indicators (i.e., \% organic matter, chironomids) showed clearer evidence of the

567 Younger Dryas in the White Mountains synchronously with the Atlantic Provinces, but to a

568 lesser extent (Cwynar and Spear 2001). The steep topography in the mountain ranges of

569 northeastern North America could reinforce these climatic variations, supported by the

570 orographic effect. There is, however, a lack of data to distinguish how the impacts of the

571 different climatic fluctuations are related to zonal (e.g., latitude) and azonal (e.g., distance to

572 the ocean, topography) variables;

573 3) On a regional scale, there is also an important difference in the quantity of data available, with

574 some ranges having been studied more thoroughly than others. Alpine environments of 
575 northeastern North America are characterized by non-linear responses due to interactions and

576 feedbacks between geological, geomorphological, ecological and climatic factors. This

577 complexity results in singular environments exhibiting a resilient permafrost state despite

578 being at boundary conditions, a unique arctic-alpine flora on the summits, original geomorphic

579 processes such as the frost-coated clast flows (Hétu et al. 1994), climatic particularities like

580 the extreme winds on Mount Washington and puzzling ecological dynamics like the lowering

581 of the treeline in the Gaspé Peninsula despite the warming trend of the climate. Therefore, a

582 global and thorough understanding of the alpine environment of northeastern North America

583 remains a scientific challenge. In the context of the ongoing climate change, which could

584 result in profound alterations of these systems, it is the opinion of the authors that an

585 integrated and multi-proxy approach (Lotter, 2003) would be necessary to get a valuable

586 prospective view of the evolution of these altitudinal bio-geo-ecosystems.

\section{5. Conclusions}

590 Through different case studies, this synthesis underlined the imbricated interactions of Pre-

591 Holocene history with the Late-Glacial and Holocene evolution of climate, biosystems and

592 geosystems leading to the modern alpine landscapes. Regional ice recession and postglacial

593 vegetation establishment followed a south to north temporal trend, with each mountain range

594 displaying a distinct evolution. However, there is a need for further studies on mountain

595 environments to better understand, among others, the origin and evolution of the felsenmeers on

596 the summits of many ranges discussed in this paper, the impacts and duration of cold-based vs

597 warm-based glaciers on the shaping of the alpine landscapes, and the complexity of this

598 environment at the regional scale. Further studies using innovative datation techniques in this 
599 study region, such as cosmogenic nuclide dating (e.g. Gosse et al. 2006), Schmidt hammer (e.g.

600 Matthews and Wilson, 2015) or optically stimulated luminescence (e.g. Rémillard et al. 2015)

601 could refine the resolution and enhance our understanding of the evolution of the alpine

602 environment of the Northeast. The case studies presented above show how the complex

603 interactions between the different systems underlie the presence of alpine environments at such

604 low elevations, their different responses in terms of landscape evolution and of their resilience to

605 climate change.

606

607 The synergistic interactions between the different systems demonstrate the need for an

608 interdisciplinary approach in order to better understand how this unique environment will evolve

609 in the coming decades. Capers et al. (2013) recognized this need by doing a survey of scientists

610 from diverse disciplinary fields to establish alpine research priorities in the Northeast, but the bias

611 towards ecology is still apparent in the proposed research projects. The paraglacial concept seems

612 to be a promising framework within which to achieve this interdisciplinary need, since it

613 considers the landscape as a complex system that integrates many feedbacks at different temporal

614 scales (Mercier 2008). There is a need to broaden its definition further by considering ecological

615 dynamics not only as variables influencing the sedimentary budget, but as an inherent subsystem

616 of the paraglacial environment, and by recognizing the overlapping spatial scales with regards to

617 the temporal duration of the paraglacial period and to its dominant processes. Finally, the

618 synthesis of the climate proxies presented in Figure 5 shows that alpine ranges responded

619 differently to major climatic changes and highlights the relevance of a multi-proxy approach in

620 reconstructing past alpine environments. Some hypotheses were proposed to explain the

621 discrepancies between the different records. The fact that the studies were only conducted locally

622 and many decades apart might be the primary cause of these inconsistencies. The complex 
623 systems of alpine environment of the Northeast are characterized by their nonlinear responses. As

624 an example, in some fine-grained scree slopes of the Gaspé Peninsula, due to an increased

625 sediment flux related to frost-coated clast flows over the last decades, the altitude of the treeline

626 is decreasing since the middle of the twentieth century even considering the ongoing climate

627 warming favourable to the growth of the tree cover. In this regard, there is a need for broader-

628 scale multi-proxy research since the uniqueness of the alpine landscapes of northeastern North

629 America holds keys to better understanding past and upcoming environmental changes (Germain 630 and Hétu, in press).

631

632 Acknowledgements

633

634 This research was financially supported by the Fonds québécois de Recherche sur la Nature et les

635 Technologies through a scholarship granted to J.P. Martin. The authors would like to thank

636 Gabriel Magnan, Pierre Richard, Patrick Lajeunesse and especially Michelle Garneau for their

637 thoughtful insights that contributed to this review, as well as André Parent who assisted in the 638 design of the figures.

639

640 References

641

642 Anderson, R.S. and Davis, R.B. 1986. History of late- and post-glacial vegetation and disturbance 643 around Upper South Branch Pond, northern Maine. Canadian Journal of Botany, 64: 1977-1986.

644 doi: $10.1139 / \mathrm{b} 86-262$

645 
646 Anderson, T.W., Levac, E. and Lewis, M.C.F. 2007. Cooling in the Gulf of St. Lawrence and 647 estuary region at 9.7 to $7.214 \mathrm{C}$ ka (11.2-8.0 cal ka): Palynological response to the PBO and 8.2

648 cal ka cold events, Laurentide Ice Sheet air-mass circulation and enhanced freshwater runoff.

649 Palaeogeography, Palaeoclimatology, Palaeoecology, 246: 75-100. doi:

$650 \quad 10.1016 /$ j.palaeo.2006.10.028

651

652 Asnong, H. and Richard, P.J.H. 2003. La végétation et le climat postglaciaires du centre et de 653 l'est de la Gaspésie, au Québec. Géographie physique et Quaternaire, 57(1): 37-63. doi:

$654 \quad 10.7202 / 010330 \mathrm{ar}$

655

656 Bailey, S.W., Hoy, J. and Cogbill, C.V. 2015. Vascular flora and geoecology of Mont de la

657 Table, Gaspésie, Québec. Rhodora, 117(969): 1-40. doi: 10.3119/14-07

658

659 Ballantyne, C.K. 2002. Paraglacial geomorphology. Quaternary Science Reviews, 21: 1935-

660 2017. doi: 10.1016/S0277-3791(02)00005-7

661

662 Beckage, B., Osborne, B., Gavin, D.G., Pucko, C., Siccama, T. and Perkins, T. 2008 A rapid

663 upward shift of a forest ecotone during 40 years of warming in the Green Mountains of Vermont.

664 Proceedings of the National Academy of Science, 105(11): 4197-4202. doi:

$66510.1073 /$ pnas.0708921105

666

667 Birks, H.H. and Birks, H.J.B. 2000. Future uses of pollen analysis must include plant 668 macrofossils. Journal of Biogeography, 27(1): 31-35. doi: 10.1046/j.1365-2699.2000.00375.x 669 
670 Bishop, P. 2007. Long-term landscape evolution: linking tectonics and surface processes. Earth

671 Surface Processes and Landforms, 32; 329-365 doi: 10.1002/esp.1493

672

673 Bogucki, D.J. 1977. Debris slide hazard in the Adirondack Province of New York State.

674 Environmental Geology, 1: 317-328. doi: 10.1007/BF02380500

675

676 Bradley, D.C. 1981. Late Wisconsinan Mountain Glaciation in the Northern Presidential Range,

677 New Hampshire. Arctic and Alpine Research, 13(3): 319-327. doi: 10.2307/1551038

678

679 Burakowski, E.A., Wake, C.P., Braswell, B., Brown, D.P. 2008. Trends in wintertime climate in 680 the northeastern United States: 1965-2005. Journal of Geophysical Research, 113(D20). doi:

$681 \quad 10.1029 / 2008 J D 009870$

682

683 Bussières, B., Payette, S. and Filion, L. 1996. Déboisement et entourbement des hauts sommets 684 de Charlevoix à l'Holocène supérieur: origine des étages alpin et subalpin. Géographie physique 685 et Quaternaire, 50(3): 257-269. doi: 10.7202/033099ar

686

687 Camill, P. and Clark, J.S. 2000. Long-Term Perspectives on Lagged Ecosystem Responses to 688 Climate Change : Permafrost in Boreal Peatlands and the Grassland/Woodland Boundary.

689 Ecosystems, 3(6): 534-544. doi: 10.1007/s100210000047

690

691 Capers, R.S., Kimball, K.D., McFarland, K.P., Jones, M.T., Lloyd, A.H., Munroe, J.S., Fortin, 692 G., Mattrick, C., Goren, J., Sperduto, D.D. and Paradis, R. 2013. Establishing alpine research 
693 priorities in Northeastern North America. Northeastern Naturalist, 20(4): 559-577. doi:

$694 \quad 10.1656 / 045.020 .0406$

695

696 Capers, R.S. and Stone, A.D. 2011 After 33 years, trees more frequent and shrubs more abundant 697 in Northeast U.S. alpine community. Arctic, Antarctic and Alpine Research, 43(4): 495-502. doi: $698 \quad 10.1657 / 1938-4246-43.4 .495$

699

700 Carlson, B.Z., Munroe, J.S. and Hegman, B. 2011 Distribution of Alpine Tundra in the

701 Adirondack Mountains of New York, U.S.A. Arctic, Antarctic and Alpine Research, 43(3): 331-

702 342. doi: $10.1657 / 1938-4246-43.3 .331$

703

704 Clark, G.M. and Schmidlin, T.W. 1992. Alpine periglacial landforms of eastern North America:

705 A review. Permafrost and Periglacial Processes, 3(3): 225-230. doi: 10.1002/ppp.3430030309

706

707 Cogbill, C.V. 1985. Dynamics of boreal forest of the Laurentian Highlands, Canada. Canadian

708 Journal of Forest Research, 15: 252-261. doi: 10.1139/x85-043

709

710 Cogbill, C.V. and White, P.S. 1991. The Latitude-Elevation Relationship for Spruce-Fir Forest

711 and Treeline alond the Appalachian Mountain Chain. Vegetatio, 94(2): 153-175. doi:

$712 \quad 10.1007 / \mathrm{BF} 00032629$

713

714 Cwynar, L.C. and Spear, R.W. 2001. Lateglacial climate change in the White Mountains of New

715 Hampshire. Quaternary Science Reviews, 20: 1265-1274. doi: 10.1016/S0277-3791(00)00151-7

716 
717 Davis, P.T. and Davis, R.B. 1980. Interpretation of minimum-limiting radiocarbon dates for 718 deglaciation of Mount Katahdin area, Maine. Geology, 8(4): 396-400. doi: 10.1130/0091-7613 719

720 Dullinger, S., Gattringer, A., Thuiller, W., Moser, D., Zimmermann, N.E., Guisan, A., Willner, 721 W., Plutzar, C., Leitner, M., Mang, T., Caccianiga, M., Dirnböck, T., Ertl, S., Fischer, A., Lenoir, 722 J., Svenning, J.C., Psomas, A., Schmartz, D.R., Silc, U., Vittoz, P. and Hübler, K. 2012.

723 Extinction debt of high-mountain plants under twenty-first century climate change. Nature 724 Climate Change, 2: 619-622. doi: 10.1038/nclimate1514 725

726 Dumais, C., Ropars, P., Denis, M.P., Dufour-Tremblay, G. and Boudreau, S. 2014. Are low 727 altitude alpine tundra ecosystems under threat? A case study from the Parc National de la 728 Gaspésie, Québec. Environmental Research Letters, 9: 1-10. doi: 10.1088/1748-9326/9/9/094001 729

730 Dyke, A.S., Andrews, J.T., Clark, P.U., England, J.H., Miller, G.H., Shaw, J. and Veillette, J.J. 731 2002. The Laurentide and Innuitian ice sheets during the Last Glacial Maximum. Quaternary 732 Science Reviews, 21: 9-31. doi: 10.1016/S0277-3791(01)00095-6 733

734 Dyke, A.S. 2004. An outline of North American Deglaciation with an emphasis on central and 735 northern Canada. In Quaternary Glaciations - Extent and Chronology, Part II: North America. 736 Edited by J. Ehlers and P.L. Gibbard. Developments in Quaternary Science, 2b. Elsevier, 737 Amsterdam, Netherlands. pp. 373-424.

738

739 Engler, R., Randin, C.F., Thuiller, W., Dullinger, S., Zimmermann, N., Araujo, M.B., Pearman, 740 P.B., Le Lay, G., Piedallu, C., Albert, C.H., Choler, P., Coldea, G., De Lamo, X., Dirnböck, T., 
741 Gégout, J.C., Gomez-Garcia, D., Grytnes, J.A., Heegard, E., Høistad, F., Nogués-Bravo, D.,

742 Normand, S., Puşcaş, M., Sebastià, M.T., Stanisci, A., Theurillat, J.P., Trivedi, M.R., Vittoz, P.

743 and Guisan, A. 2011. $21^{\text {st }}$ century climate change threatens mountain flora unequally across

744 Europe. Global Change Biology, 17(7): 2330-2341. doi: 10.1111/j.1365-2486.2010.02393.x

745

746 Enos, P.C. 1969. Cloridorme Formation, middle Ordovician Flysch, Northern Gaspé Peninsula,

747 Québec. Geological Society of America Special Paper, 117. doi: 10.1130/SPE117-p1

748

749 Fernald, M.L. 1907. The soil preferences of certain alpine and subalpine plants. Rhodora Journal 750 of the New England Botanical Club, 9(105): 149-193.

751

752 Fernald, M.L. 1925. Persistence of plants in unglaciated areas of Boreal America. Memoirs of the

753 American Academy of Arts and Sciences, 15: 558-572. doi: 10.2307/25058128

754

755 Filion, L. 1987. Holocene Development of Parabolic Dunes in the Central St. Lawrence Lowland,

756 Québec. Quaternary Research, 28: 196-209. doi: 10.1016/0033-5894(87)90059-7

757

758 Fortin, G. and Hétu, B. 2014. Estimating winter trends in climatic variables in the Chic-Chocs

759 Mountains, Canada (1970-2009). International Journal of Climatology, 34: 3078-3088. doi:

$760 \quad 10.1002 /$ joc. 3895

761

762 Gądek, B. 2012. Debris slopes ventilation in the periglacial zone of the Tatra Mountains (Poland

763 and Slovakia) : The indicators. Cold Regions Science and Technology, 74-75: 1-10. doi:

$764 \quad 10.1016 /$ j.coldregions.2012.01.007 
766 Germain, D. 2005. Dynamique des avalanches de neige en Gaspésie, Québec, Canada. Ph.D.

767 thesis, Department of Geography, Laval University, Québec, Canada.

768

769 Germain, D. and Hétu, B. (in press) Hillslope processes and related sediment fluxes on a fine-

770 grained scree slope of Eastern Canada. In Source-to-sink fluxes in Undisturbed Cold

771 Environments. Edited by A.A. Beylich, J.C. Dixon and Z. Zwolinski. Cambridge University

772 Press, Cambridge, UK.

773

774 Germain, D., Hétu, B. and Filion, L. 2010. Tree-ring based reconstruction of past snow avalanche

775 events and risk assessment in Northern Gaspé Peninsula (Québec, Canada). In Tree rings and

776 natural hazards. Edited by M. Stoffel, M. Bollschweiler, D.R. Butler and B.H. Luckman.

777 Springer, Dordrecht, Netherlands. pp. 51-73.

778

779 Gordon, G. 1989. The Worst Weather in the World. Windswept, 30: 66-69.

780

781 Gosse, J.C., Bell, T., Gray, J.T., Klein, J., Yang, G. and Finkel, R. 2006. Using cosmogenic

782 isotopes to interpret the landscape record of glaciation : Nunataks on Newfoundland ? In Glacier

783 science and environmental change. Edited by P.J. Knight. Blackwell, Oxford, UK. pp. 442-446.

784

785 Grabherr, G., Gottfried, M. and Pauli, H. 2010. Climate change impacts in alpine environments.

786 Geogaraphy Compass, 4(8): 1133-1153. doi: 10.1111/j.1749-8198.2010.00356.x

787 
788 Gray, J.T. and Brown, R.J.E. 1979. Permafrost presence and distribution in the Chic-Chocs

789 Mountains, Gaspésie, Québec. Géographie physique et Quaternaire, 33(3-4): 299-316. doi:

$790 \quad 10.7202 / 1000366 a r$

791

792 Gray, J.T., Godin, É., Masse, J. and Fortier, D. 2009. Trois décennies d'observation des

793 fluctuations du régime thermique du pergélisol dans le parc national de la Gaspésie. Le

794 naturaliste canadien, 133(3): 69-77.

795

796 Hargraves, R.B., Roy, D.W. 1974. Paleomagnetism of Anorthosite in and around the Charlevoix

797 Cryptoexplosion Structure, Quebec. Canadian Journal of Earth Sciences, 11: 854-859. doi:

$798 \quad 10.1139 / \mathrm{e} 74-085$

799

800 Harris, C., Arenson, L.U., Christiansen, H.H., Etzelmüller, B., Frauenfelder, R., Gruber, S.,

801 Haeberli, W., Hauck, C., Hözle, M., Humlum, O., Isaksen, K., Kääb, A., Kern-Lütschg, M.A.,

802 Lehning, M., Matsuoka, N., Murton, J.B., Nötzli, J., Phillips, M., Ross, N., Seppälä, M.,

803 Springman, S.M. and Mühll, D.V. 2009. Permafrost and climate in Europe: Monitoring and

804 modelling thermal, geomorphological and geotechnical responses. Earth-Science Reviews, 92;

805 117-171. doi: 10.1016/j.earscirev.2008.12.002

806

807 Harsch, M.A., Hulme, P.E., McGlone, M.S., Duncan, R.P. 2009. Are treelines advancing ? A

808 global meta-analysis of treeline response to climate warming. Ecology Letters, 12: 1040-1049.

809 doi: 10.1111/j.1461-0248.2009.01355.x

810 
811 Hétu, B. and Bail, P. 1996. Évolution postglaciaire du regime hydrosédimentaire et vitesse de

812 l'ablation dans un petit basin-versant des Appalaches près de Rimouski (Bas-Saint-Laurent,

813 Québec). Géographie physique et Quaternaire, 50(3): 351-363.

814

815 Hétu, B. and Gray, J.T. 2000. Effects of environmental change on scree slope development

816 throughout the postglacial period in the Chic-Choc Mountains in the northern Gaspe Peninsula,

817 Quebec. Geomorphology, 32: 335-355. doi: 10.1016/S0169-555X(99)00103-8

818

819 Hétu, B., Van Steijn, H. and Vandelac, P. 1994. Les coulées de pierres glacées: un nouveau type

820 de coulées de pierraille sur les talus d'éboulis. Géographie physique et Quaternaire, 48:3-22. doi:

821 10.7202/032969ar

822

823 Hiscott, R.N. and James, N.P. 1985. Carbonate debris flows, Cow Head Groupe, western

824 Newfoundland. Journal of Sedimentary Research, 55(5): 735-745.

825

826 Humlum, O. 1998. The climatic significance of rock glaciers. Permafrost and Periglacial

827 Processes, 9(4): 375-395. doi: 10.1002/(SICI)1099-1530

828

829 Ibe, R.A. 1985. Postglacial Montane Vegetational History Around Balsam Lake, Catskill

830 Mountains, New York. Bulletin of the Torrey Botanical Club, 112(2): 176-186. doi:

$831 \quad 10.2307 / 2996414$

832

833 Jackson, S.T. and Whitehead, D.R. 1991. Holocene vegetation patterns in the Adirondack

834 Mountains. Ecology, 72(2): 641-653. doi: 10.2307/2937204 
836 Johansson, M., Callaghan, T.V., Rosiö, J. and Akerman, H.J. 2013. Rapid responses of

837 permafrost and vegetation to experimentally increased snow cover in sub-arctic Sweden.

838 Environmental Research Letter, 8(3): 035025. doi: 10.1088/1748-9326/8/3/035025

839

840 Johnson, C.J., Ehlers, L.P.W. and Seip, D.R. 2015. Witnessing extinction - Cumulative impacts

841 across landscapes and the future loss of an evolutionarily significant unit of woodland caribou in

842 Canada. Biological Conservation, 186: 176-186. doi: 10.1016/j.biocon.2015.03.012

843

844 Jomelli, V., Khodri, M., Favier, V., Brunstein, D., Ledru, M.P., Wagnon, P., Blard, P.H., Sicart,

845 J.E., Braucher, R., Grancher, D., Bourlès, D.L., Braconnot, P. and Vuille, M. 2011. Irregular

846 tropical glacier retreat over the Holocene epoch driven by progressive warming. Nature, 474:

847 196-199. doi: 10.1038/nature 10150

848

849 Jones, M.T. and Willey, L.L. 2012. The Eastern Alpine Guide. Beyond Ktaadn and Boghaunter

850 Books, New Salem, Massachusetts.

851

852 Jutras, P. and Schroeder, J. 1999. Geomorphology of an exhumed Carboniferous paleosurface in

853 the southern Gaspé Peninsula, Québec; paleoenvironmental and tectonic implications.

854 Géographie physique et Quaternaire, 53(2): 249-263. doi: 10.7202/005690ar

855

856 Körner, C. 1998 A re-assessment of high elevation treeline positions and their explanation.

857 Oecologia, 115: 445-459. doi: 10.1007/s004420050540

858 
859 Kull, C.A. and Magilligan, F.J. 1994. Controls over landslide distribution in the White

860 Mountains, New Hampshire. Physical Geography, 15(4): 325-341. doi:

$861 \quad 10.1080 / 02723646.1994 .10642520$

862

863 Labelle, C. and Richard, P.J.H. 1984. Histoire Postglaciaire de la Végétation dans la Région de

864 Mont-Saint-Pierre, Gaspésie, Québec. Géographie physique et Quaternaire, 38(3): 257-274. doi:

$86510.7202 / 032567 \mathrm{ar}$

866

867 Lafortune, M., Filion, L. and Hétu, B. 1997. Dynamique d'un front forestier sur un talus

868 d'éboulis actif en climat tempéré froid (Gaspésie, Québec). Géographie physique et Quaternaire,

869 51(1): 1-15. doi: 10.7202/004840ar

870

871 Lavoie, M. and Richard, P.J.H. 2000. Paléoécologie de la tourbière du Lac Malbaie, dans le

872 Massif des Laurentides (Québec): Évaluation du rôle du climat sur l'accumulation de la tourbe.

873 Géographie physique et Quaternaire, 54(2): 169-185. doi: 10.7202/004843ar

874

875 Lebuis, J. and David, P.P. 1977. La stratigraphie et les évènements du Quaternaire de la partie 876 occidentale de la Gaspésie, Québec. Géographie physique et Quaternaire, 31(3-4): 275-296. doi:

$877 \quad 10.7202 / 1000278$ ar

878

879 Lotter, A.F. 2003. Multi-proxy climatic reconstructions. In Global change in the Holocene.

880 Edited by A. Mackay, R. Battarbee, J. Birks and F. Oldfield. Arnold, London, UK. pp. 373-383. 881 
882 Löve, D. 1970. Subarctic and Subalpine: Where and What? Arctic and Alpine Research, 2(1): 63883 73. doi: $10.2307 / 1550141$

884

885 Matthews, J.A. and Wilson, P. 2015. Improved Schmidt-hammer exposure ages for active and 886 relict pronival ramparts in southern Norway, and their palaeoenvironmental implications.

887 Geomorphology, 246: 7-21. doi: 10.1016/j.geomorph.2015.06.002

888

889 Mercier, D. 2008. Paraglacial and paraperiglacial landsystems : concepts, temporal scales and

890 spatial distribution. Géomorphologie : relief, processus, environnement, 4: 223-234. doi:

891 10.4000/geomorphologie.7396

892

893 Messerli, B. and Ives, J.D. 1997. Mountains of the world: A global priority. Parthenon Publishing 894 Group, UK.

895

896 Morard, S., Delaloye, R. and Lambiel, C. 2010. Pluriannual thermal behaviour of low elevation 897 cold talus slopes (western Switzerland). Geographica Helvetica, 65(2): 124-134. doi: 10.5194/gh$898 \quad 65-124-2010$

899

900 Olejczyk, P. and Gray, J.T. 2007. The relative influence of Laurentide and local ice sheets during

901 the last glacial maximum in the eastern Chic-Chocs Range, northern Gaspé Peninsula, Quebec.

902 Canadian Journal of Earth Sciences, 44: 1603-1625. doi: 10.1139/e07-039

903

904 Price, M., Jansky, L. and Iatsenia, A.A. 2004. Key issues for Mountain Areas. United Nations 905 University press, Tokyo. 
907 Putnam, A.E. and Putnam, D.E. 2009. Inactive and relict rock glaciers of Deboullie Lakes

908 Ecological Reserve, northern Maine, USA. Journal of Quaternary Science, 24(7): 773-784. doi:

$909 \quad 10.1002 /$ jqs.1252

910

911 Reimer, P.J., Baillie, M.G.L., Bard, E., Bayliss, A., Beck, J.W., Blackwell, P.G., Bronk Ramsey,

912 C., Buck, C.E., Burr, G.S., Edwards, R.L., Friedrich, M., Grootes, P.M., Guilderson, T., Hajdas,

913 I., Heaton, T., Hogg, A., Hughen, K., Kaiser, K., Kromer, B., McCormac, F., Manning, S.,

914 Reimer, R., Richards, D., Southon, J., Talamo, S., Turney, C., van der Plicht, J. and

915 Weyhenmeye, C. 2009. INTCAL09 and MARINE09 Radiocarbon age calibration curves, 0-

91650,000 years cal BP. Radiocarbon, 51: 1111-1150.

917

918 Rémillard, A.M., Hétu, B., Bernatchez, P., Buylaert, J.P., Murray, A.S., St-Onge, G., Geach, M.

919 2015. Chronology and palaeoenvironmental implications of the ice-wedge pseudomorphs and

920 composite-wedge casts on the Magdalen Islands. Boreas, 44(4): 658-675. doi: 10.1111/bor.12125

921

922 Richard, P.J.H. 2009. Chronologie de la déglaciation: de l’importance des années étalonnées

923 (calibrées). Association Québécoise pour l'étude du Quaternaire. Available from:

924 http://www.er.uqam.ca/nobel/aqqua1/articles/ChronoDeglaciation.pdf

925

926 Richard, P.J.H., Veillette, J.J., Larouche, A.C., Hétu, B., Gray, J.T. and Gangloff, P. 1997.

927 Chronologie de la déglaciation en Gaspésie: nouvelles données et implications. Géographie

928 physique et Quaternaire, 51(2): 163-184. doi: 10.7202/033116ar

929 
930 Robinson, S.C., Ketchledge, E.H., Fitzgerald, B.T., Raynald, D.J. and Kimmerer, R.W. 2010. A

931 23-year assessment of vegetation composition and change in the Adirondack alpine zone, New

932 York State. Rhodora, 112: 355-377. doi: 10.3119/09-03.1

933

934 Rochefort, R.M., Little, R.L., Woodward, A. and Peterson, D.L. 1994. Changes in sub-alpine tree

935 distribution in western North America: a review of climatic and other causal factors. The

936 Holocene 4(1): 89-100. doi: 10.1177/095968369400400112

937

938 Sagoff, M. 2002. On the Value of natural Ecosystems: The Catskills Parable. Politics and the Life 939 Sciences, 21(1): 19-25.

940

941 Seidel, T.M., Weihrauch, D., Kimball, K.D., Pszenny, A., Soboleskil, R., Crete, E. and Murray,

942 G. 2009. Evidence of climate change declines with elevation based on temperature and snow

943 records from 1930s to 2006 on Mount Washington, New Hampshire, USA. Arctic, Antarctic and

944 Alpine Research, 41: 362-372. doi: 10.1657/1938-4246-41.3.362

945

946 Shur, Y.L. and Jorgenson, M.T. 2007. Patterns of permafrost formation and degradation in

947 relation to climate and ecosystems. Permafrost and Periglacial Processes, 17: 7-19. doi:

$948 \quad 10.1002 /$ ppp.582

949

950 Sirois, L. 1984. Le plateau du mont Albert: étude phyto-écologique. Master thesis, Biology

951 Department, Laval University, Québec, Canada.

952 
953 Spear, R.W. 1989. Late-Quaternary History of High-Elevation Vegetation in the White

954 Mountains of New Hampshire. Ecological Monographs, 59(2): 125-151. doi: 10.2307/2937283

955

956 Spear, R.W., Davis, M.B. and Shane, L.C.K. 1994. Late Quaternary History of Low- and Mid-

957 Elevation Vegetation in the White Mountains of New Hampshire. Ecological Monographs, 64(1):

958 85-109. doi: 10.2307/2937056

959

960 Sprugel, D.G. 1976. Dynamic structure of wave-regenerated Abies balsamea forests in the

961 northeastern United States. Journal of Ecology, 64: 889-905. doi: 10.2307/2258815

962

963 Thorson, R.M. and Schile, C.A. 1995. Deglacial eolian regimes in New England. Geological

964 Society of America Bulletin, 107(7): 751-761. doi: 10.1130/0016-7606(1995)

965

966 Titus, R. 2004. The Catskills: A Geological Guide, 3rd Edition. Purple Mountain Press, 967 Fleischmann, New York.

968

969 Wahl, K., Spooner, I. and Colville, D. 2007. Thin-Skinned Debris Flows in Cape Breton

970 Highlands National Park, Nova Scotia, Canada. Atlantic Geology, 43: 45-56. doi:

$9712048 / 10.4138 / 4213$

972

973 Walegur, M.T. and Nelson, F.E. 2003. Permafrost distribution in the Appalachian Highlands, 974 northeastern USA. In Permafrost. Edited by Philips, Springman and Anderson. Liss, Swets and 975 Zeitlinger, pp. 1201-1206.

976 
977 Whipple, K.X. 2009. The influence of climate on the tectonic evolution of mountain belts. Nature 978 geoscience, 2: 97-104. doi: 10.1038/ngeo413

979

980 Winkworth, R.C., Wagstaff, S.J., Glenny, D. and Lockhart, P.J. 2005. Evolution of the New 981 Zealand mountain flora: Origins, diversification and dispersal. Organisms, Diversity \&

982 Evolution, 5: 237-247. doi: 10.1016/j.ode.2004.12.001

983

984 Yagouti, A., Boulet, G. and Vescovi, L. 2006. Projet-MNEV-7 : Homogénéisation des séries de 985 températures et analyse de la variabilité spatio-temporelle de ces séries au Québec méridional.

986 Rapport \#4 - Homogénéisation des séries de températures du Québec méridional et analyse de 987 l'évolution du climat à l'aide d'indicateurs. Consortium Ouranos, Québec, Canada.

988

989 Zimmermann, C. and Lavoie, C. 2001. A paleoecological analysis of a southern permafrost

990 peatland, Charlevoix, Quebec. Canadian Journal of Earth Sciences, 38: 909-919. doi:

$991 \quad 10.1139 / \mathrm{e} 00-110$

992

993

994

995

996

997

998

999

1000 


\begin{tabular}{lccccc} 
Range Name & $\begin{array}{c}\text { Surface } \\
\text { area }\left(\mathbf{k m}^{2}\right)\end{array}$ & $\begin{array}{c}\text { Maximal } \\
\text { elevation }(\mathbf{m})\end{array}$ & $\begin{array}{c}\text { Area of alpine } \\
\text { environment }\left(\mathbf{k m}^{2}\right)\end{array}$ & $\begin{array}{c}\text { Proportion of alpine } \\
\text { environment (\%) }\end{array}$ & $\begin{array}{c}\text { Minimal elevation of } \\
\text { alpine environment }(\mathbf{m})\end{array}$ \\
\hline $\begin{array}{l}\text { Adirondacks } \\
\text { (High Peaks) }\end{array}$ & 1200 & 1629 & 0.7 & 0.06 & 1350 \\
\hline $\begin{array}{l}\text { White } \\
\text { Mountains }\end{array}$ & $3500(\mathrm{e})$ & 1917 & 11.3 & 0.32 & $1330(\mathrm{e})$ \\
\hline $\begin{array}{l}\text { Mount } \\
\text { Katahdin }\end{array}$ & 809 & 1606 & 7.3 & 0.90 & $1200(\mathrm{e})$ \\
\hline $\begin{array}{l}\text { Charlevoix } \\
\text { Highlands }\end{array}$ & $1000(\mathrm{e})$ & 1180 & $2.25(\mathrm{e})$ & 0.23 & $700(\mathrm{e})$ \\
\hline $\begin{array}{l}\text { Chic-Chocs } \\
950(\mathrm{e})\end{array}$ & 1261 & $45(\mathrm{e})$ & 4.97 & $900(\mathrm{e})$ \\
\hline $\begin{array}{l}\text { Long Range } \\
4100(\mathrm{e})\end{array}$ & 812 & $>500(\mathrm{e})$ & 12.19 & $200(\mathrm{e})$
\end{tabular}

1001

1002 Table 1: Physiographic characteristics of different alpine ranges of northeastern North America 1003 across a SW (Adirondacks) to NE (Long Range) gradient. Data with an (e) represent rough

1004 estimates made by the author using satellite imagery (Google Earth). 


\begin{tabular}{|c|c|c|c|c|}
\hline Range & Location & $\begin{array}{l}\text { Latitude } \\
\left({ }^{\circ}\right)\end{array}$ & Dated material & Sources \\
\hline Catskills & $\begin{array}{l}\text { Balsam Lake } \\
\text { (762 m a.s.I.) }\end{array}$ & 42.1 & $\begin{array}{l}\text { Inferred from age- } \\
\text { depth curve }\end{array}$ & Ibe, 1985 \\
\hline Adirondacks & $\begin{array}{l}\text { Upper Wallface } \\
\text { Pond } \\
\text { (948 m a.s.I.) }\end{array}$ & 44.1 & Pond sediment & $\begin{array}{l}\text { Jackson and } \\
\text { Whitehead, } 1991\end{array}$ \\
\hline $\begin{array}{l}\text { White } \\
\text { Mountains }\end{array}$ & $\begin{array}{l}\text { Deer Lake Bog } \\
(1,325 \text { m a.s.I. }) \\
\end{array}$ & 44.3 & Pond sediment & Spear ,1989 \\
\hline $\begin{array}{l}\text { Mount } \\
\text { Katahdin }\end{array}$ & $\begin{array}{l}\text { Lower Tongue } \\
\text { Pond } \\
\text { (183 m a.s.I.) }\end{array}$ & 45.9 & Lake sediment & $\begin{array}{l}\text { Davis and Davis, } \\
1980\end{array}$ \\
\hline $\begin{array}{l}\text { Charlevoix } \\
\text { Highlands }\end{array}$ & $\begin{array}{l}\text { Lac Malbaie } \\
\text { (800 m a.s.l.) }\end{array}$ & 47.8 & Peat & $\begin{array}{l}\text { Lavoie and Richard, } \\
2000\end{array}$ \\
\hline \multirow{3}{*}{$\begin{array}{l}\text { Chic-Chocs } \\
\text { high } \\
\text { plateaux }\end{array}$} & $\begin{array}{l}\text { Lac du Diable } \\
\text { (494 m a.s.I.) }\end{array}$ & \multirow{3}{*}{48.9} & Gyttja & Richard et al, 1997 \\
\hline & $\begin{array}{l}\text { Lac Côté } \\
\text { (915 m a.s.l.) }\end{array}$ & & $\begin{array}{l}\text { Organic matter } \\
\text { above sand and silt }\end{array}$ & $\begin{array}{l}\text { Lebuis and David, } \\
1977\end{array}$ \\
\hline & $\begin{array}{l}\text { Lac Bouliane } \\
\text { (992 m a.s.l.) }\end{array}$ & & Gyttja & Richard et al., 1997 \\
\hline \multirow{2}{*}{$\begin{array}{l}\text { Chic-Chocs } \\
\text { low plateaux }\end{array}$} & $\begin{array}{l}\text { Lac du Triangle } \\
\text { (465 m a.s.I.) }\end{array}$ & \multirow[t]{2}{*}{49.2} & $\begin{array}{l}\text { Dryas integrifolia } \\
\text { and Salix } \\
\text { herbaceae }\end{array}$ & $\begin{array}{l}\text { Asnong and Richard, } \\
2003\end{array}$ \\
\hline & $\begin{array}{l}\text { Lac Turcotte } \\
\text { (457 m a.s.l.) }\end{array}$ & & $\begin{array}{l}\text { Marl interbedded } \\
\text { with gyttja }\end{array}$ & $\begin{array}{l}\text { Labelle and Richard, } \\
1984\end{array}$ \\
\hline $\begin{array}{l}\text { Chic-Chocs } \\
\text { coastal } \\
\text { valleys } \\
\end{array}$ & 60 m a.s.l. & 49.2 & Hiatella arctica & Hétu and Gray, 2000 \\
\hline Long Range & NA & 49.6 & NA & Dyke, 2004 \\
\hline
\end{tabular}

1016 Table 2 : Sites used in the deglaciation reconstruction. 


\begin{tabular}{|c|c|c|c|c|}
\hline Range & Location & $\begin{array}{l}\text { Altitude } \\
\text { (m a.s.I.) }\end{array}$ & $\begin{array}{c}\text { Latitude } \\
\left({ }^{\circ}\right)\end{array}$ & Sources \\
\hline Catskills & Balsam Lake & 762 & 42.1 & Ibe, 1985 \\
\hline Adirondacks & $\begin{array}{l}\text { Heart Lake } \\
\text { Livingstone Pond } \\
\text { Upper Wallface Pond } \\
\text { Elk Pass Bog } \\
\text { Lake Arnold } \\
\text { Lake Tear of the Clouds }\end{array}$ & $\begin{array}{c}661 \\
850 \\
948 \\
1,024 \\
1,150 \\
1,320\end{array}$ & 44.1 & Jackson and Whitehead, 1991 \\
\hline White Mountains & $\begin{array}{l}\text { Mirror Lake } \\
\text { Lost Pond } \\
\text { Little East Pond } \\
\text { Lonesome Lake } \\
\text { Carter Notch Pond } \\
\text { Kinsman Pond } \\
\text { Eagle Lake Bog } \\
\text { Deer Lake Bog } \\
\text { Lake of the Clouds }\end{array}$ & $\begin{array}{c}213 \\
625 \\
793 \\
831 \\
1,004 \\
1,140 \\
1,275 \\
1,325 \\
1,542\end{array}$ & 44.3 & Spear et al. 1994 \\
\hline Mount Katahdin & Upper South Branch Pond & 300 & 45.9 & Anderson et al. 1986 \\
\hline Charlevoix Highlands & $\begin{array}{l}\text { Lac Malbaie } \\
\text { Lac à l'Empêche } \\
\text { Lac des Cygnes Mountain }\end{array}$ & $\begin{array}{l}800 \\
950 \\
960\end{array}$ & 47.8 & $\begin{array}{l}\text { Lavoie and Richard, } 2000 \\
\text { Bussières et al. } 1996 \\
\text { Zimmerman and Lavoie, } 2000\end{array}$ \\
\hline Chic-Chocs high plateaux & Lac du Diable & 494 & 48.9 & Richard et al, 1997 \\
\hline Chic-Chocs low plateaux & Lac Turcotte & 457 & 49.2 & Labelle and Richard, 1984 \\
\hline Chic-Chocs coastal valleys & Lac à Léonard & 17 & 49.2 & Labelle and Richard, 1984 \\
\hline
\end{tabular}

1026 Table 3: Sites used in the paleoecological reconstructions. 


\section{Figure captions}

1036

1037 Figure 1: Worldwide atitudinal treeline elevation, showing the unique character of northeastern

1038 North America. White dots present data from ranges discussed in this article. From South to

1039 North (left to right on the figure): Adirondacks (New York), Green Mountains (Vermont), White

1040 Mountains (New Hampshire), Mount Katahdin (Maine), Charlevoix Highlands (Quebec), Chic-

1041 Chocs (Quebec), Long Range (Newfoundland). Worldwide data from Körner (1998).

1042

1043 Figure 2: Major alpine environments of northeastern North America used in this study. 1)

1044 Catskills; 2) Adirondack Mountains; 3) Green Mountains; 4) White Mountains; 5) Mount

1045 Katahdin; 6) Cape Breton Highlands; 7) Charlevoix Highlands; 8) Chic-Chocs and McGerrigle

1046 Mountains; and 9) Long Range.

1047

1048 Figure 3: Time of establishment of the vegetation stages on different ranges of the northeastern

1049 North America. The white line represents the tundra stage (unavailable for the Chic-Chocs

1050 coastal plateaux), the gray line represents the afforestation stage and the black line represents the

1051 closed-forest stage (unavailable for the Catskills). The top two are from Gaspé Peninsula

1052 lowland. The gray boxes represent Late-Glacial and Early Holocene cold episodes (from left to

1053 right: Younger Dryas, Preboreal Oscillation and 8,200 BP cooling period). The black trendline

1054 represents minimum glacial recession age, with error bars related to either different data sources

1055 or from radiocarbon calibration.

1056

1057 Figure 4: Modern and paleo-permafrost elevation following an elevation-latitude gradient. The 1058 dashed lines represent the modern elevation of permafrost (upper dashed line) and of cold talus 
1059 scree slopes (lower dashed line). The solid line represents the Early-Holocene elevation of 1060 permafrost, as inferred from rock glacier elevations. Even today, the ventilation system of the 1061 cold scree slopes provides them with sufficient thermic resilience to exist at similar altitudes as 1062 the Early-Holocene rock glaciers (Modified from Putnam and Putnam, 2009).

1063

1064 Figure 5: Climatic indicators of the different alpine regions of northeastern North America 1065 Straight arrows represent indicators of colder episodes. Waved arrows represent indicators of 1066 warmer episodes. PBO: Pre-Boreal Oscillation; MWP: Medieval Warm Period; LIA: Little Ice 1067 Age 


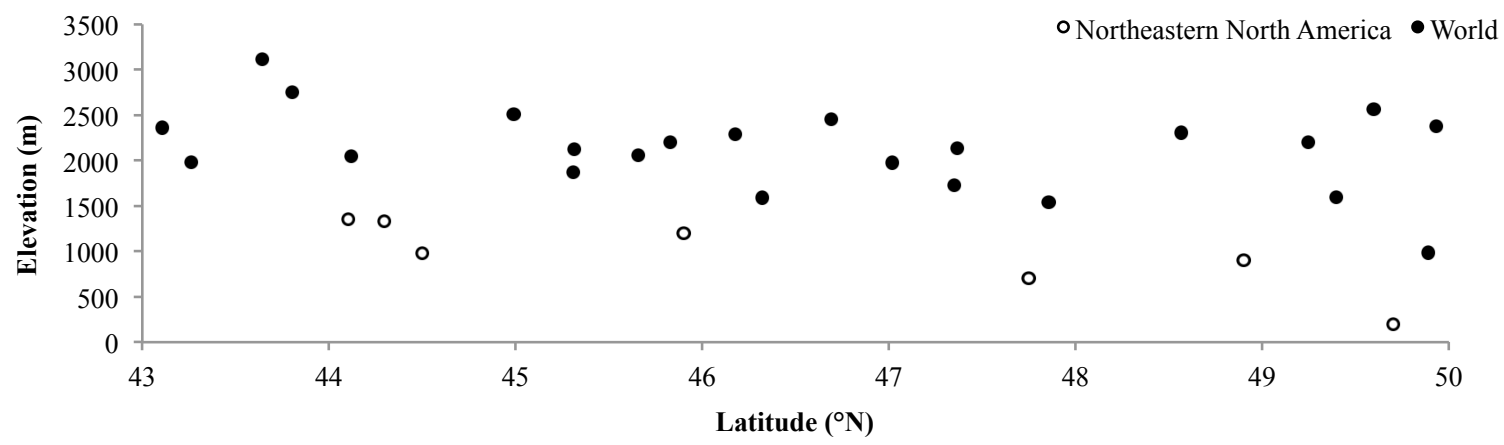

Figure 1: Worldwide atitudinal treeline elevation, showing the unique character of northeastern North America. White dots present data from ranges discussed in this article. From South to North (left to right on the figure): Adirondacks (New York), Green Mountains (Vermont), White Mountains (New Hampshire), Mount Katahdin (Maine), Charlevoix Highlands (Quebec), ChicChocs (Quebec), Long Range (Newfoundland). Worldwide data from Körner (1998). 


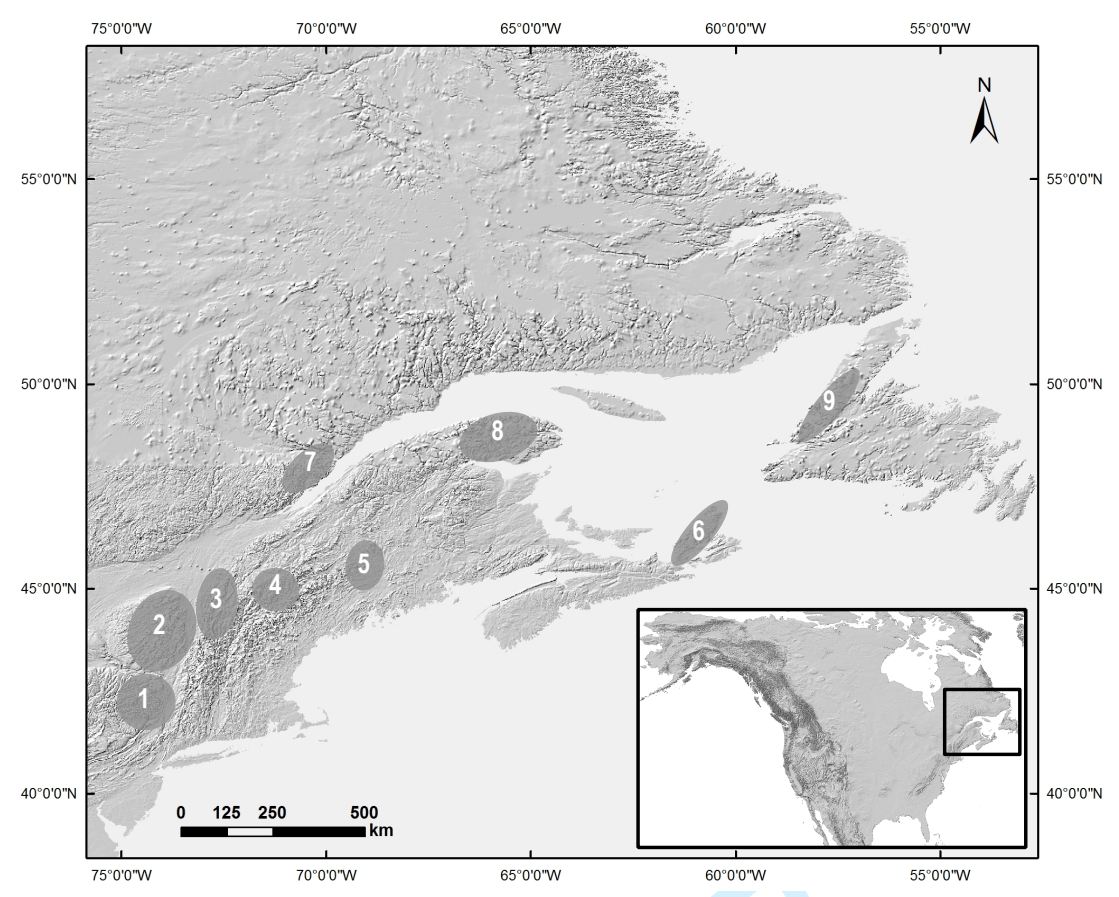

Figure 2: Major alpine environments of northeastern North America. 1) Catskills; 2) Adirondack Mountains; 3) Green Mountains; 4) White Mountains; 5) Mount Katahdin; 6) Cape Breton Highlands; 7) Charlevoix Highlands; 8) Chic-Chocs and McGerrigle Mountains; and 9) Long Range. 


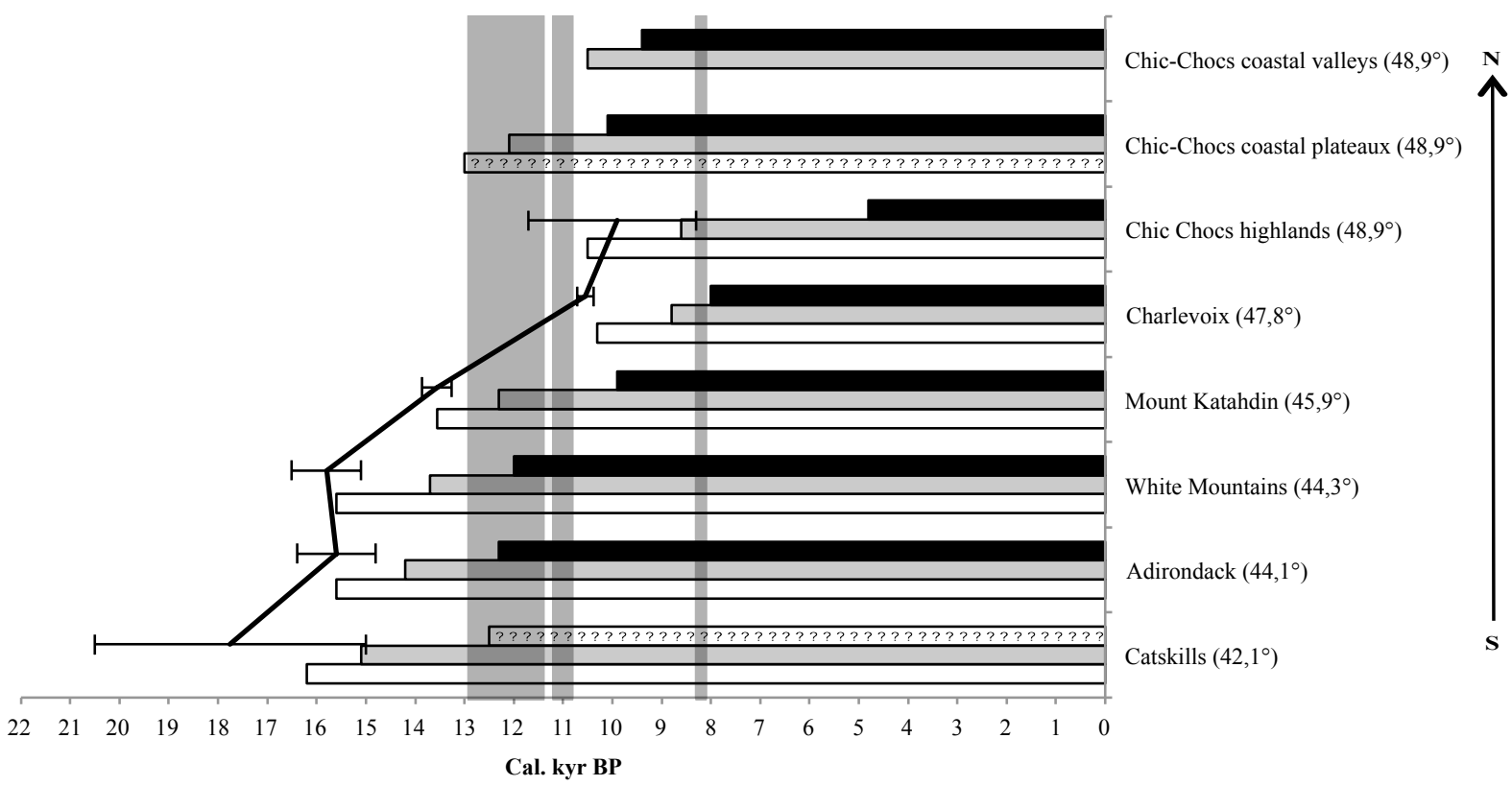

Figure 3: Time of establishment of the vegetation stages on different ranges of the northeastern North America. The white line represents the tundra stage (unavailable for the Chic-Chocs coastal plateaux), the gray line represents the afforestation stage and the black line represents the closed-forest stage (unavailable for the Catskills). The top two are from Gaspé Peninsula lowland. The gray boxes represent Late-Glacial and Early Holocene cold episodes (from left to right: Younger Dryas, Preboreal Oscillation and 8,200 BP cooling period). The black trendline represents minimum glacial recession age, with error bars related to either different data sources or from radiocarbon calibration. 


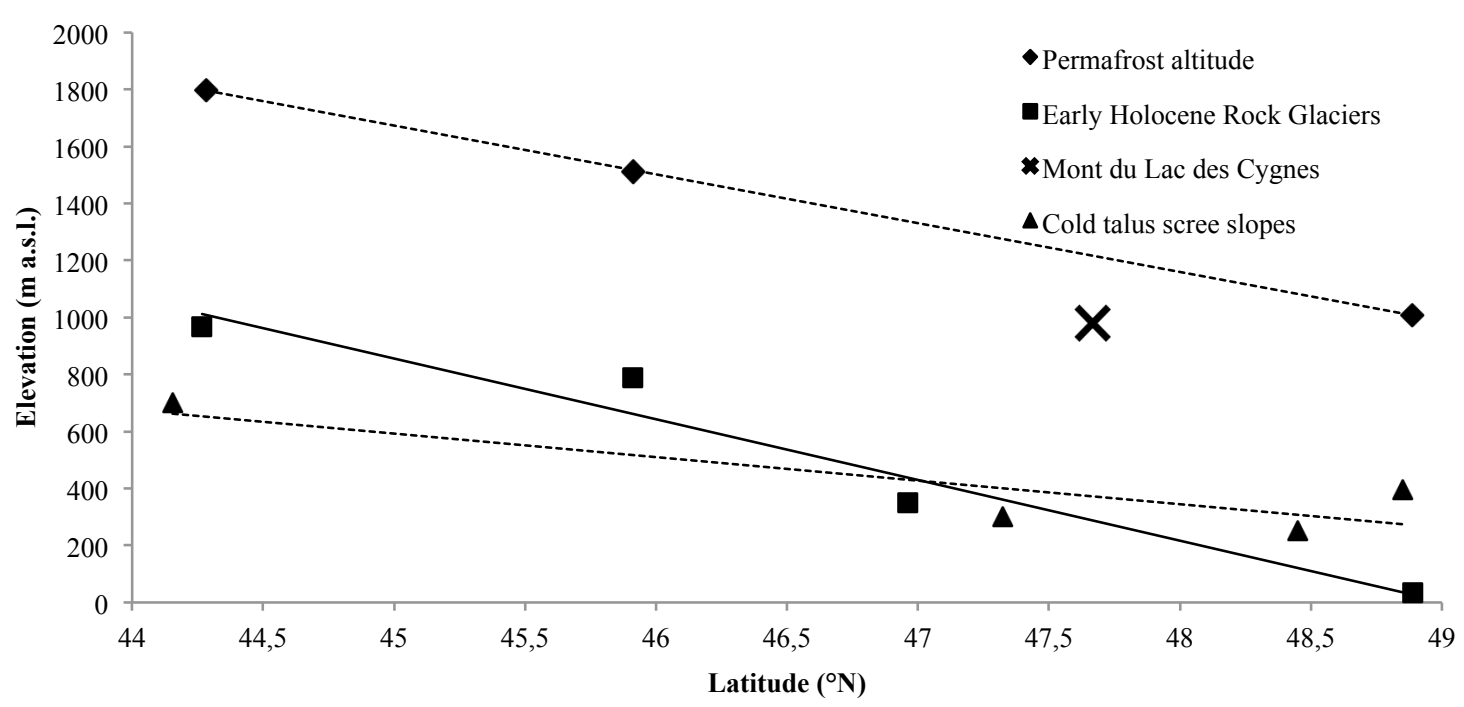

Figure 4: Modern and paleo-permafrost elevation following an elevation-latitude gradient. The dashed lines represent the modern elevation of permafrost (upper dashed line) and of cold talus scree slopes (lower dashed line). The solid line represents the Early-Holocene elevation of permafrost, as inferred from rock glacier elevations. Even today, the ventilation system of the cold scree slopes provides them with sufficient thermic resilience to exist at similar altitudes as the Early-Holocene rock glaciers (Modified from Putnam and Putnam, 2009). 


\begin{tabular}{|c|c|c|c|c|c|c|c|}
\hline Range & $\begin{array}{l}\text { Older } \\
\text { Dryas }\end{array}$ & $\begin{array}{l}\text { Younger } \\
\text { Dryas }\end{array}$ & $\begin{array}{l}\mathrm{PBO} / 8200 \mathrm{BP} \\
\text { cooling episodes }\end{array}$ & Climatic Optimum & Neoglacial & MWP & $\begin{array}{l}\text { LIA/ } \\
\text { Present }\end{array}$ \\
\hline \multirow[t]{2}{*}{ Chic-Chocs } & $14.5-13.8$ & $12.9-11.4$ & 11.1-8.1 & \multirow{2}{*}{$\begin{array}{l}\text {-Pinus strobus maximum } \\
\text {-Podzols at high elevations } \\
->\text { solifluxion at high elevations } \\
\text {-Stabilisation of debris fans }\end{array}$} & $1.4-0.9$ & & $0.15-0$ \\
\hline & $\begin{array}{l}\text { Moraines, } \\
\text { fluvioglacial } \\
\text { deltas }\end{array}$ & $\begin{array}{l}\text { Moraines, } \\
\text { fluvioglacial } \\
\text { deltas }\end{array}$ & $\begin{array}{l}\text { - Glacial cirques } \\
\text { - Rock glaciers } \\
\text { - Slushflow fans } \\
\text { - Alnus crispa } \text { expansion } \\
\text { - Variation in herbaceous } \\
\text { vegetation }\end{array}$ & & \begin{tabular}{l|}
-Snow avalanches \\
with geomorphic \\
impacts \\
-Peat accumulation in \\
avalanche runout \\
zones
\end{tabular} & & $\begin{array}{l}-\lambda \text { vegetation } \\
\text { elevation on } \\
\text { scree slopes }\end{array}$ \\
\hline \multirow[t]{2}{*}{ Charlevoix } & & $12.9-11.4$ & & \multirow{2}{*}{$\overbrace{\text { Peat accumulation }}^{6.6-4.5}$} & $3.2-0.0$ & & \\
\hline & & $\begin{array}{l}\text { St. Narcisse } \\
\text { moraine }\end{array}$ & & & $\begin{array}{l}\text { - High fire frequency } \\
\text { - Vegetation low } \\
\text { regeneration rate } \\
\text { - Peat accumulation on } \\
\text { summits }\end{array}$ & & $\underset{\begin{array}{l}\text { Inception of } \\
\text { permafrost on } \\
\text { summits }\end{array}}{\stackrel{0.5-0.0}{\longrightarrow}}$ \\
\hline New England & $\underset{\begin{array}{l}\text { Bethleem } \\
\text { moraine }\end{array}}{\stackrel{14.5-13.8}{\longrightarrow}}$ & $\begin{array}{l}\stackrel{12.9-11.4}{\longrightarrow}-\backslash \% \text { organic } \\
\text { matter in peat } \\
-\searrow \text { loss on } \\
\text { ingnition } \\
-\succ \text { treeline } \\
\text { altitude }\end{array}$ & $\begin{array}{l}\text { Pinus strobus } \\
\text { altitudinal } \\
\text { maximum }\end{array}$ & $\begin{array}{l}\searrow \text { treeline elevation } \\
\text { to present-day } \\
\text { altitude }\end{array}$ & & & \\
\hline
\end{tabular}

Figure 5: Climatic indicators of the different alpine regions of northeastern North America Straight arrows represent indicators of colder episodes. Waved arrows represent indicators of warmer episodes. PBO: Pre-Boreal Oscillation; MWP: Medieval Warm Period; LIA: Little Ice Age 